\title{
Microspheres prepared with biodegradable PHBV and PLA polymers as prolonged-release system for ibuprofen: in vitro drug release and in vivo evaluation
}

\author{
Giovana Carolina Bazzo*, Aline Teixeira de Macedo, Janine Paula Crenca, Virgínia Emiliana Silva, \\ Eduardo Manoel Pereira, Melissa Zétola, Bianca Ramos Pezzini
}

Department of Pharmacy, Regional University of Joinville

\begin{abstract}
In this study, poly(hydroxybutyrate-co-hydroxyvalerate) (PHBV) and poly(l-lactide) (PLA) microspheres containing ibuprofen were prepared with the aim of prolonging the drug release. The oil-in-water $(\mathrm{O} / \mathrm{W})$ emulsion solvent evaporation technique was used, varying the polymer ratio. All formulations provided spherical particles with drug crystals on the surface and a porous and rough polymeric matrix when PHBV was used and smooth external surface when prepared with PLA. The in vitro dissolution profiles show that the formulation containing PHBV/PLA at the proportion of 30/70 presented the best results in terms of prolonging the ibuprofen release. The analysis of the concentration of ibuprofen in the blood of rats showed that maximum levels were achieved at between one and two hours after administration of the immediate-release form (pure drug), while the prolonged microspheres led to a small amount of the drug being released within the first two hours and reached the maximum level after six hours of administration. It was concluded that it is possible to prolong the release of ibuprofen through its incorporation into PHBV/PLA microspheres.
\end{abstract}

Uniterms: Microspheres/preparation. Poly(hydroxybutyrate-co-hydroxyvalerate). Poly(l-lactide). Ibuprofen/release. Drugs/controlled release/in vitro study. Drugs/controlled release/in vivo evaluation.

No presente estudo foram preparadas microesferas de poli(hidroxibutirato-co-hidroxivalerato) (PHBV) e poli(ácido láctico) (PLA) com o objetivo de prolongar a liberação do ibuprofeno, utilizado como fármaco modelo. Empregou-se o método de emulsificação e evaporação do solvente óleo em água $(\mathrm{O} / \mathrm{A})$, variando-se a proporção entre os polímeros. Todas as formulações originaram partículas esféricas com cristais de fármaco aderidos à superfície externa. As microesferas apresentaram superfície rugosa e porosa, quando o PHBV foi utilizado, e superfície externa lisa, quando preparadas com o PLA. Os perfis de dissolução in vitro evidenciaram que a formulação que continha PHBV/PLA na proporção de 30/70 apresentou melhores resultados para prolongar a liberação do ibuprofeno. Através da análise da concentração de ibuprofeno no plasma de ratos, após administração oral, verificou-se que os níveis máximos ocorreram entre 1 e 2 horas após a administração de ibuprofeno não encapsulado, enquanto o fármaco presente nas microesferas atingiu um pico máximo após 6 horas da administração. Conclui-se, portanto, que é possível prolongar a liberação do ibuprofeno após a sua incorporação às microesferas preparadas com os polímeros PHBV e PLA, especialmente na proporção de 30/70.

Unitermos: Microesferas/preparação. Poli(hidroxibutirato-co-hidroxivalerato). Poli(ácido láctico). Ibuprofeno/liberação. Fármacos/liberação controlada/estudo in vitro. Fármacos/liberação controlada/ avaliação in vivo.

*Correspondence: G. C. Bazzo. Departamento de Farmácia, Universidade da Região de Joinville. Rua Paulo Malschitzki, 10, Campus Universitário - Zona Industrial, 89219-710 - Joinville - SC, Brasil. E-mail: gbazzo@uol.com.br 


\section{INTRODUCTION}

The incorporation of drugs into polymeric microspheres can be employed in the pharmaceutical field for various purposes including the controlled-release of the drug in order to maintain therapeutic drug levels over a specified time period (Thompson et al., 2007). In this way it is possible to reduce the number of daily administrations of the drug and, also, to reduce the side effects.

Polymers such as polylactide (PLA) and poly(lactide-co-glycolide) (PLGA) have been successfully used to prepare micro- and nanoparticulate drug delivery systems as well as other medical devices, like sutures and implants (Kuo et al., 2012; Umeki et al., 2010; Ishii et al., 2007; Sastre et al., 2007). Pharmaceutical products based on PLA and PLGA microparticles loaded with hormones, antitumor drugs and antibiotics are already available in the market in Europe and the U.S. (Dorati et al., 2007).

The polyhydroxyalkanoates (PHAs), which are biodegradable and biocompatible polyesters synthesized by bacteria, represent another group of polymers widely used for pharmaceutical purposes, including microparticulate drug carriers. The most common PHAs are poly(3hydroxybutyrate) (PHB) and the related copolymer with 3-hydroxyvalerate (PHBV). The degradation product of these polymers, 3-hydroxybutyric acid, is a common metabolite in all higher living beings indicating their nontoxicity (Freier et al., 2002; Pouton, Akhtar, 1996). Both PHB and PHBV have been used to prepare micro- and nanoparticles containing ibuprofen (Bidone et al., 2009), piroxicam (Bazzo et al., 2010) and alendronate (Huang et al., 2009). However, in many cases, these polymers originate rough and porous microparticles that promote rapid drug release. Therefore, the association of PHAs with other biocompatible and biodegradable polymers like PLA is an interesting strategy to obtain microparticles with different morphological characteristics able to prolong the drug release.

The aim of the study reported herein was to prepare a microsphere system comprised of a PHBV and PLA blend to prolong the release of ibuprofen. This drug, a nonsteroidal anti-inflammatory (NSAID), is a good candidate for prolonged drug release systems due its short plasmatic half live, which requires many daily administrations. Also, this drug can be taken by other routes, such as intraarticular administration, where a biodegradable microparticulate system is advantageous (Fernández-Carballido et al., 2004). The effect of the PHBV/PLA ratio on the ibuprofen in vitro release from the microspheres was evaluated and an investigation into absorption in rats was carried out.

\section{MATERIAL AND METHODS}

\section{Material}

PHBV and PLA were kindly supplied by PHB Industrial S.A. (Serrana, SP, Brazil). Ibuprofen was purchased from Pharma Nostra (Rio de Janeiro, RJ, Brazil) and poly(vinyl alcohol) from Vetec Química (Rio de Janeiro, RJ, Brazil). Dichloromethane, acetone, sodium hydroxide and hydrochloric acid were acquired from Biotec Reagentes Analíticos (Pinhais, PR, Brazil) and isopropyl alcohol from F. Maia (Cotia, SP, Brazil). All chemicals were used without further purification.

\section{Preparation of the microspheres}

The microspheres were prepared through the $\mathrm{O} / \mathrm{W}$ emulsion solvent evaporation technique. Briefly, $500 \mathrm{mg}$ of polymer(s) and $200 \mathrm{mg}$ of ibuprofen were dissolved in dichloromethane (internal phase) and then emulsified in $200 \mathrm{~mL}$ of $0.15 \%$ (w/v) PVA aqueous solution (external phase) containing $10 \mathrm{~mL}$ of isopropyl alcohol and acidified to $\mathrm{pH} 3.0$ with $\mathrm{HCl}(1 \% \mathrm{v} / \mathrm{v})$. The resulting emulsion was stirred at $700 \mathrm{rpm}$, at room temperature for $24 \mathrm{~h}$ until the evaporation of the organic solvent. The microparticles were washed with distilled water, centrifuged, dried and stored under vacuum at room temperature.

They were prepared in different formulations (named A, B, C and D), varying the polymer ratio, according to Table I. Microspheres were also prepared without the drug according to the above-described procedure.

\section{Loading efficiency (LE)}

Approximately $10 \mathrm{mg}$ of microspheres were weighed and dissolved in $10 \mathrm{~mL}$ of dichloromethane. The solution was diluted to give a concentration of $20.0 \mathrm{mg}$ $\mathrm{L}^{-1}$ of ibuprofen and the UV absorption was determined on a Shimadzu (1601PC) UV/Vis spectrophotometer $(\lambda=227 \mathrm{~nm})$. The loading efficiency was calculated from a calibration curve prepared in the range of 5.0 and $25.0 \mathrm{mg} \mathrm{L}^{-1}$.

\section{Scanning electron microscopy (SEM)}

The morphology of the microparticles was examined using a Philips XL30 scanning electron microscope. The arithmetic mean diameter of at least 100 particles was measured on micrographs obtained by SEM. 


\section{In vitro drug release}

The in vitro drug release was carried out in phosphate buffer solution $\mathrm{pH} 6.8$ at $37 \pm 1^{\circ} \mathrm{C}$. Approximately $10 \mathrm{mg}$ of microspheres was suspended in $45 \mathrm{~mL}$ of phosphate buffer and maintained in a thermostated oscillating bath for 8 hours. After pre-determined time intervals an aliquot of the release medium $(4 \mathrm{~mL})$ was withdrawn and the samples were immediately returned to the dissolution vessels after analysis. The samples were then analyzed by $\mathrm{UV} /$ Vis spectrophotometry $(\lambda=227 \mathrm{~nm})$ and the amount of drug released was calculated. The percentage of drug release in $1 \mathrm{~h}(\mathrm{Q} \%)$ was used to compare the formulations with respect to burst release and the dissolution efficiency (DE) at $8 \mathrm{~h}$ was used to compare the prolonged drug release profiles. The dissolution efficiency is given by Equation 1. The data were evaluated by analysis of variance (ANOVA) followed by the application of the Tukey test, using the software GraphPad Prism ${ }^{\circledR}$.

$$
D E=\frac{\int y d t}{t}
$$

where $y$ denotes the percentage of dissolved drug and $t$ is time.

\section{In vivo study}

\section{Animals}

Male Wistar rats (Rattus norvegicus), weighing 250$300 \mathrm{~g}$ were used in this study. The animals were obtained from the Technological Institute of Paraná (TECPAR) and were maintained, six per cage, in the central bioterium of UNIVILLE in rooms with a dark-light cycle of 12 hours (lights on at 7 a.m. and off at 7 p.m.) and controlled temperature of $20 \pm 2{ }^{\circ} \mathrm{C}$. Animals had access to food and water ad libitum. All procedures involving animals were performed according to the national guidelines for studies using animals and the recommendations of the Research Ethics Committee of the University of Joinville. The tests were conducted only after approval of the procedures by this committee.

\section{Experimental protocol}

The animals were divided into groups of six and were given $0.5 \%$ carboxymethylcellulose (CMC) solution $(0.1 \mathrm{~mL} / 100$ g, p.o.), ibuprofen $(25 \mathrm{mg} / \mathrm{kg}$, p.o.) or ibuprofen microspheres $(25 \mathrm{mg} / \mathrm{kg}$, p.o.). After different time intervals blood samples were collected in order to evaluate the levels of ibuprofen. Blood was collected by punctioning the abdominal aorta under anesthesia with xylazine $(10 \mathrm{mg} / \mathrm{kg})$ and ketamine $(90 \mathrm{mg} / \mathrm{kg})$ given intraperito- neally (Silva et al., 2010). The samples were transferred to heparinized tubes and centrifuged at $3000 \mathrm{rpm}$ for ten minutes (Nova Técnica centrifuge, model NT812). The plasma was separated and frozen at $-5{ }^{\circ} \mathrm{C}$ to be used later to quantify the ibuprofen levels by high performance liquid chromatography. Blood samples were collected one hour after treatment with $\mathrm{CMC}$ and 1,2,6 and 12 hours after administration of ibuprofen or ibuprofen microspheres, to observe the change in the drug levels over time.

\section{Blood sample analysis}

The plasmatic concentration of ibuprofen was determined by high performance liquid chromatography (HPLC), using an adaptation of the methodology described in Li et al. (2008). Plasma $(200 \mu \mathrm{L})$ was mixed with acetonitrile $(700 \mu \mathrm{L})$ and centrifuged at $3000 \mathrm{rpm}$ for $10 \mathrm{~min}$. The supernatant was analyzed by HPLC (Merck Hitachi D7000) equipped with a LiChrospher ${ }^{\circledR} \mathrm{RP}-18(5 \mu \mathrm{m})$ column.

The mobile phase consisted of acetonitrile (A) and MILLI-Q ${ }^{\circledR}$ water (W) following the gradient: 1 $\min (20 \% \mathrm{~A} / 80 \% \mathrm{~W}), 5 \min (40 \% \mathrm{~A} / 60 \% \mathrm{~W}), 8 \mathrm{~min}$ $(50 \% \mathrm{~A} / 50 \% \mathrm{~W}), 11 \mathrm{~min}(70 \% \mathrm{~A} / 30 \% \mathrm{~W})$ and $15 \mathrm{~min}$ $(80 \% \mathrm{~A} / 20 \% \mathrm{~W})$. The eluent was monitored at $220 \mathrm{~nm}$ with a flow rate of $1.0 \mathrm{~mL} \mathrm{~min}^{-1}$.

\section{RESULTS AND DISCUSSION}

\section{Microsphere morphology and loading efficiency}

The micrographs of the external surface of the microspheres are presented in Figures 1 and 2. Those prepared without the drug (Figure 1) presented spherical shape and different external surface characteristics depending on the type of polymer used. The PLA microspheres had a smooth surface, as described in the literature (Umeki et al., 2010; Leo et al., 2000). In contrast, the microspheres prepared with PHBV had a rough and porous polymeric matrix, especially those prepared only with this polymer (formulation A). According to the literature, roughness and porosity are common characteristics of microparticles prepared with PHBV (Grillo et al., 2011). After the incorporation of ibuprofen, it was possible to observe drug crystals on the microsphere surfaces, especially in the case of formulations $\mathrm{C}$ and $\mathrm{D}$ (Figure 2).

Analysis of variance (ANOVA) shows that the polymer type significantly influenced the size of the microspheres $(p<0.05)$. Those prepared with PLA presented the smallest sizes and those prepared with PHBV the largest sizes, as can be seen in Table I. The microspheres prepared with PHBV and the PLA blend had intermediate diameters as expected since they were prepared using different pro- 

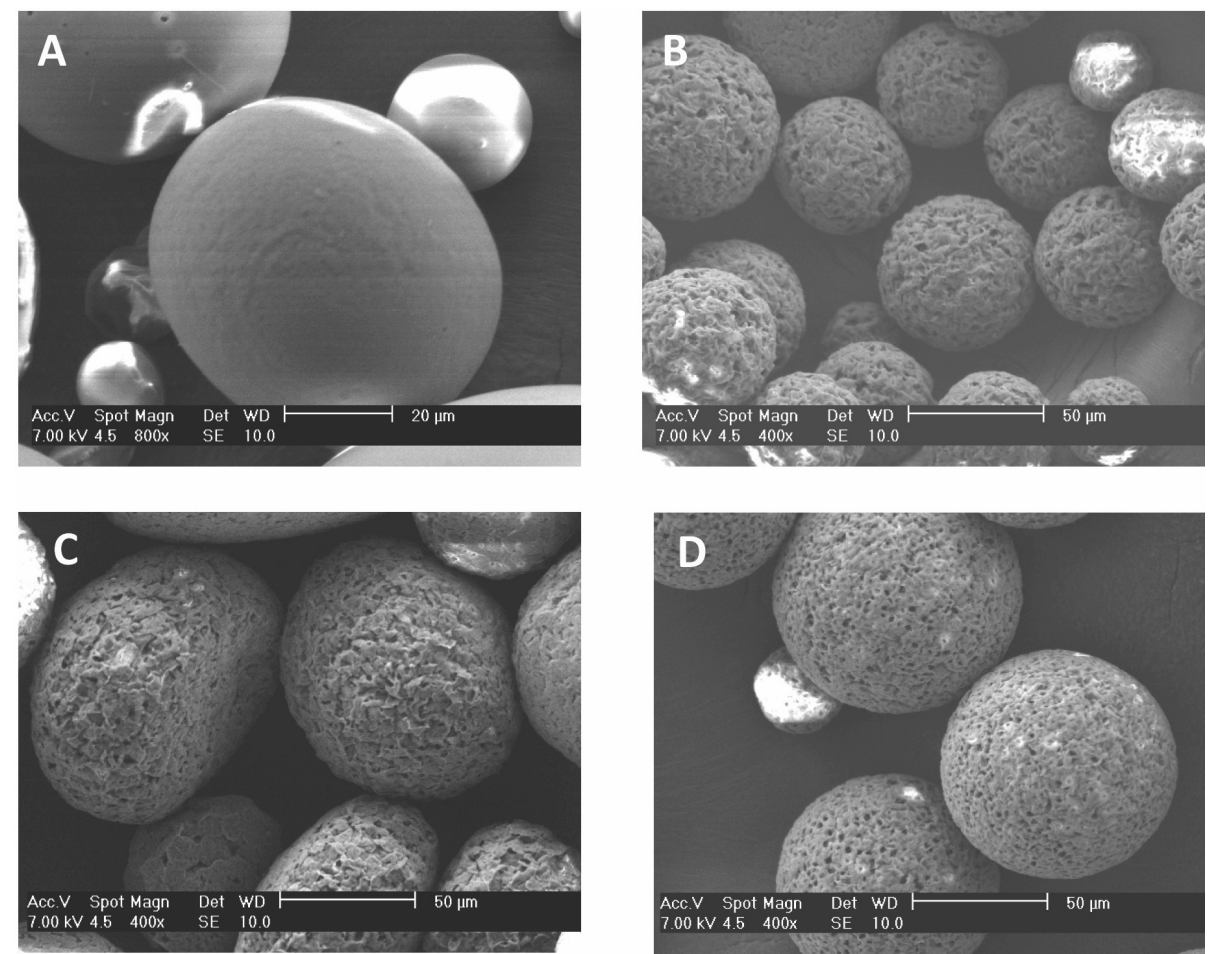

FIGURE 1 - Scanning electron micrographs of microspheres prepared without drug: (A) PLA; (B) PHBV; (C) PHBV/PLA 70/30; (D) $\mathrm{PHBV} / \mathrm{PLA} 30 / 70$.
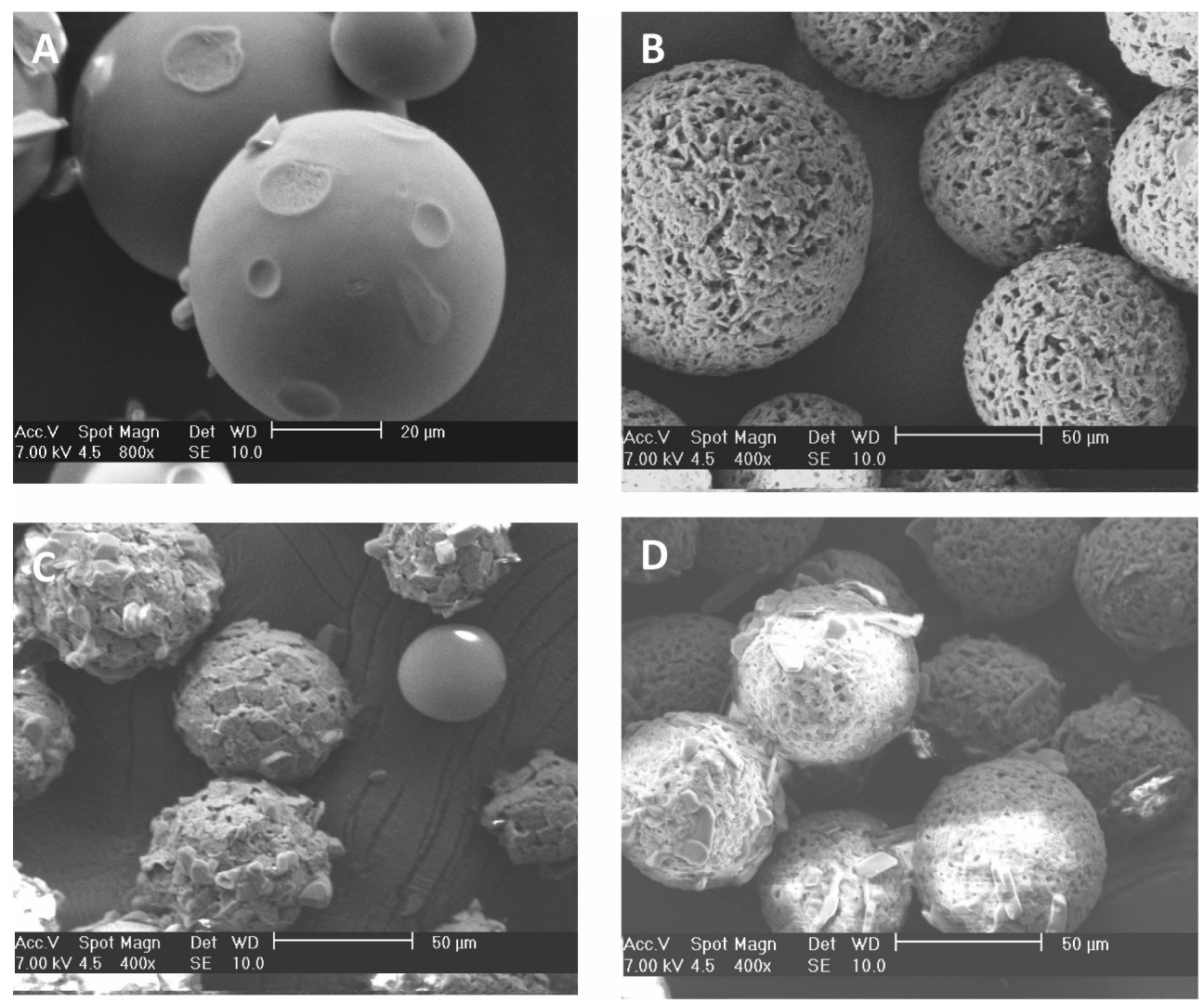

FIGURE 2 - Scanning electron micrographs of ibuprofen microspheres: (A) PLA; (B) PHBV; (C) PHBV/PLA 70/30; (D) PHBV/ PLA 30/70. 
TABLE I - PHBV/PLA microsphere formulations, loading efficiency and particle diameter

\begin{tabular}{lccc}
\hline Formulation & PHBV/PLA ratio & $\begin{array}{c}\text { Loading efficiency }(\%) \\
(\text { mean } \pm \text { S.D., } n=3)\end{array}$ & $\begin{array}{c}\text { Particle diameter }(\mu \mathrm{m}) \\
(\text { mean } \pm \text { S.D., } \mathrm{n}=100)\end{array}$ \\
\hline A & $100 / 0$ & $99.1 \pm 3.1$ & $84 \pm 13$ \\
$\mathrm{~B}$ & $0 / 100$ & $80.1 \pm 13.6$ & $49 \pm 9$ \\
$\mathrm{C}$ & $70 / 30$ & $100.4 \pm 3.4$ & $62 \pm 8$ \\
$\mathrm{D}$ & $30 / 70$ & $93.6 \pm 4.4$ & $58 \pm 11$ \\
\hline
\end{tabular}

portions of both polymers. In this case, significant differences were not observed between the particle diameters $(\mathrm{p}>0.05)$, indicating that the polymer proportions $(30 / 70$ or 70/30) did not influence the microsphere size.

High loading efficiency values were obtained for all microsphere formulations, as can be seen in Table I. There was no statistically significant difference between the LE values of the four formulations ( $p>0.05$ ), indicating that the polymer ratio does not influence the LE.

\section{In vitro drug release}

The release profiles of PHBV/PLA ibuprofen microspheres are shown in Figure 3 and indicate that the proportion of polymers greatly influenced the drug release. The formulations $\mathrm{B}$ and $\mathrm{D}$, which have a greater amount of PLA, showed a lower initial drug release and a prolonged ibuprofen release. However, those prepared with PHBV in a large quantity (formulations $\mathrm{A}$ and $\mathrm{C}$ ) rapidly released almost all of the drug.

The percentages of drug release after $1 \mathrm{~h}(\mathrm{Q} \%)$ given in Figure 4 were used to evaluate the effect of polymer ratio on the ibuprofen initial burst release. Analysis of variance shows that this variable influenced the initial drug release $(\mathrm{p}<0.05)$. Through the application of the Tukey test it was shown that there was a significant increase in $\mathrm{Q} \%$ when the proportion of PHBV in the blend was increased. It can be observed that formulation A showed the highest percentage of ibuprofen release $(87.3 \%)$ and formulation B the lowest value $(20.3 \%)$.

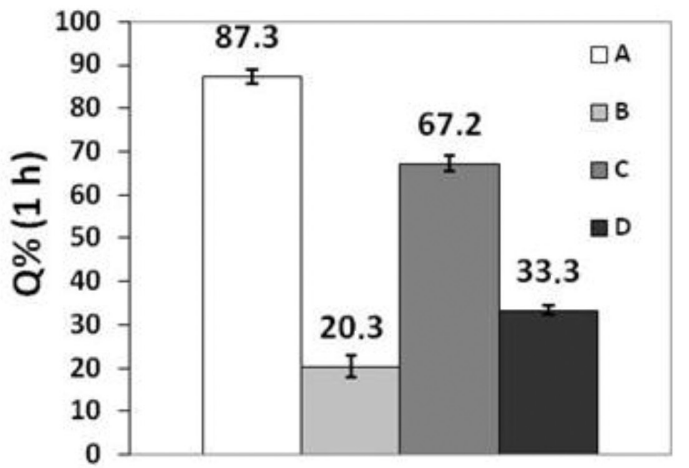

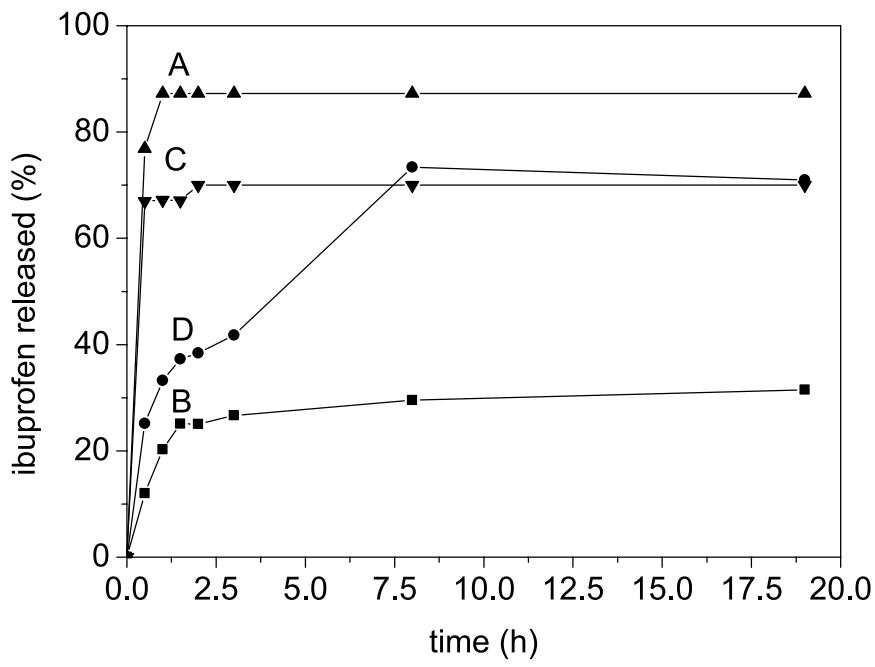

FIGURE 3 - Release profiles of PHBV/PLA/ibuprofen microspheres.

A factor that may have influenced the release of ibuprofen is the porosity of the particles along with the presence of drug crystals adhered to the outer surface of the microspheres. The rapid initial release of the drug (burst effect) is often undesirable in the case of prolonged drug release microspheres. The optimization of process conditions for the preparation of microspheres and also the development of more complex systems, such as composite microparticles, are strategies that can be used to reduce the burst release (Hassan et al., 2009). In this study, the initial drug release could be controlled by varying the proportion of polymers.

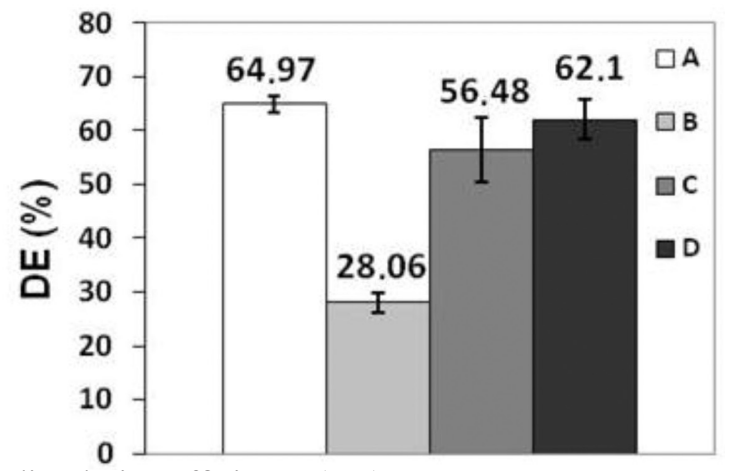

FIGURE 4 - Percentage of ibuprofen released (Q\%) after $1 \mathrm{~h}$ and dissolution efficiency (DE). 
Aiming at evaluating the effect of the proportion of the polymers on the prolonged ibuprofen release, the values for the dissolution efficiency (Figure 4) were evaluated by analysis of variance. Significant differences were observed between the $\mathrm{DE}$ values of all formulations $(p<0.05)$ except between formulations $C$ and $D(p>0.05)$. The highest values were obtained for formulation $\mathrm{A}$, which rapidly released a large amount of drug. The porosity of these microspheres probably facilitated the penetration of the dissolution medium and, consequently, facilitated the ibuprofen dissolution. It has been previously reported that PHBV microspheres could promote the fast release of ibuprofen due its porosity (Wang et al., 2007).

On the other hand, the PLA microspheres (formulation $\mathrm{B}$ ) presented the lowest DE values and a delay in the ibuprofen release. The apparent absence of pores in these microspheres, which had a smooth surface, may have contributed to prolonging excessively the release of ibuprofen. Thus, it was concluded that formulation D was the most appropriate to prolong the ibuprofen in vitro release for oral route and, therefore, this formulation was chosen for the in vivo assay.

\section{In vivo study}

The results for the plasmatic quantification of ibuprofen are shown in Figure 5 and are expressed in $\mathrm{mg} \mathrm{L}^{-1}$ for the samples collected at each time interval.

The data show that in relation to the immediate release of ibuprofen (pure drug) there was a plasmatic peak at between one and two hours. After this time, there was a progressive decline in the drug levels. After six hours,

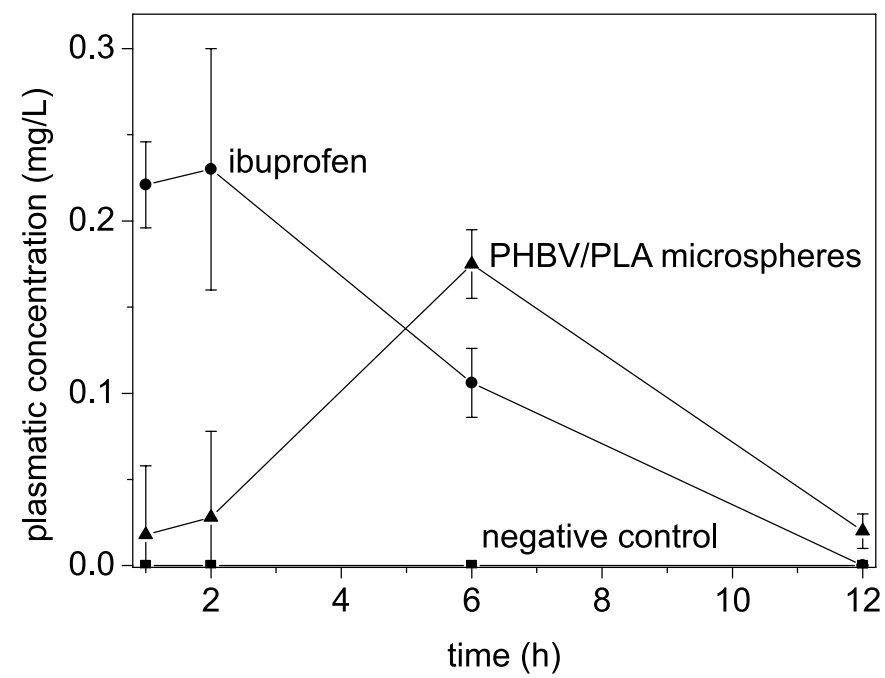

FIGURE 5 - Comparison of the ibuprofen plasmatic concentration of rats that received vehicle (negative control), ibuprofen (pure drug) and ibuprofen-loaded microspheres. around half of the maximum level was detected and, finally, at 12 hours after administration, the level of ibuprofen was at its minimum. This behavior approaches the results obtained by Khan and Akter (2005) and Bramlage and Goldis (2008), who also described peak concentrations of ibuprofen at between 1 and 2 hours after administration of its immediate-release form in rodents and humans. However, it was observed that the release profile of ibuprofen administered as microspheres was different as there was no peak in the first two hours and a higher concentration was found after six hours in comparison to the immediate-release form (pure drug). A similar decline in the concentration of ibuprofen incorporated in microspheres was observed after 12 hours in comparison to the immediate-release form.

Thus, the rate of ibuprofen release from the microspheres decreased and the highest concentration of ibuprofen was reached after a longer period of time in comparison to the immediate-release form. This result agrees with the prediction of Ashford (2005) regarding drugs incorporated in microspheres, which was the promotion of the availability of the drug for adsorption in a gradual manner when compared to the same drug given in an immediate-release system.

\section{CONCLUSIONS}

The present study shows that it is possible to obtain microspheres with different morphological characteristics and high ibuprofen loading using the biodegradable polymers PHBV and PLA in different ratios. The prolonging of the ibuprofen release was achieved when a larger amount of PLA was used. The formulation prepared with PHBV/ PLA in the ratio of 30/70 presented the best release profile of the formulations proposed, presenting the release profile more suitable for sustained release systems for oral administration. This formulation promoted a slowed in vivo release within the first two hours and prolonged the time required to reach the highest concentration to six hours after administration. The gradual release of the drug may also contribute to generating less adverse reactions, since the oscillation of the drug levels around the mean plasmatic concentration is lower, maintaining the effect within the therapeutic range.

\section{ACKNOWLEDGEMENTS}

The authors wish to thank the Fundo de Apoio à Pesquisa/ UNIVILLE and the Brazilian Government Funding Agency - Conselho Nacional de Desenvolvimento Científico e Tecnológico (CNPq) for financial support and 
Prof. Theodoro Marcel Wagner for the chromatographic analysis.

\section{REFERENCES}

ASHFORD, M. Avaliação de propriedades biofarmacêuticas. In: AULTON, M.E. Delineamento de formas farmacêuticas. 2.ed. Porto Alegre: Artmed, 2005. p.265-284.

BAZZO, G.C.; LEMOS-SENNA, E.; GONÇALVES, M.C.; PIRES, A.T.N. Effect of preparation conditions on morphology, drug content and release profiles of poly(hydroxybutyrate) microparticles containing piroxicam. J. Braz. Chem. Soc., v.19, p.914-921, 2008.

BIDONE, J.; MELO, A.P.P.; BAZZO, G.C.; CARMIGNAN, F.; SOLDI, M.; PIRES, A.T.N.; LEMOS-SENNA, E. Preparation and characterization of ibuprofen-loaded microspheres consisting of poly(3-hydroxybutyrate) and methoxy poly(ethylene glycol)-b-poly (D,L-lactide) blends or poly(3-hydroxybutyrate) and gelatin composites for controlled drug release. Mater. Sci. Eng. C., v.29, p.588593, 2009.

BRAMLAGE, P.; GOLDIS, A. Bioequivalence study of three ibuprofen formulations after single dose administration in healthy volunteers. BMC Pharmacology, v.8, p.1-9, 2005.

DORATI, R.; GENTA, I.; COLONNA, C.; PAVANETTO, F.; PERUGINI, P.; CONTI, B. Investigation of the degradation behaviour of poly(ethylene glycol-co-D,L-lactide) copolymer. Polym. Degrad. Stab., v.92, p.1660-1668, 2007.

FERNÁNDEZ-CARBALLIDO, A.F.; VANRELL, R.H.; MARTINEZ, I.T.M.; PASTORIZA, P. Biodegradable ibuprofen-loaded PLGA microspheres for intraarticular administration. Effect of Labrafil addition on release in vitro. Int. J. Pharm., v.79, p.33-41, 2004.

FREIER, T.; KUNZE, C.; NISCHAN, C.; KRAMER, S.; STERNBERG, K.; SAB, M.; HOPT, U.T.; SCHMITZ, K.P. In vitro and in vivo degradation studies for development of a biodegradable patch based on poly(3-hydroxybutyrate). Biomaterials, v.23, p.2469-2657, 2002.

GRILLO, R.; PEREIRA, A.E.S.; MELO, N.F.S.; PORTO, R.M.; FEITOSA, L.O.; TONELLO, P.S.; DIAS FILHO, N.L.; ROSA, A.H.; LIMA, R.; FRACETO, R.F. Controlled release system for ametryn using polymer microspheres: Preparation, characterization and release kinetics in water. J. Hazard Mater., v.186, p.1645-1651, 2011.
HASSAN, A.S.; SAPIN, A.; LAMPRECHT, A.; EMOND, E.; GHAZOUANI, F.; MAINCENT, P. Composite microparticles with in vivo reduction of the burst release effect. Eur. J. Pharm. Biopharm., v.73, p.337-344, 2009.

HUANG, W.; WANG, Y.; REN, L.; DU, C.; SHI, X. A novel $\mathrm{PHBV} / \mathrm{HA}$ microsphere releasing system loaded with alendronate. Mater. Sci. Eng. C., v.29, p.2221-2225, 2009.

ISHII, D.; LEE, W.K.; KASUYA, K.; IWATA, T. Fine structure and enzymatic degradation of poly[(R)-3 hydroxybutyrate] and stereocomplexed poly(lactide) nanofibers. J. Biotechnol., v.132, p.318-324, 2007.

KHAN, M.S.Y.; AKHTER, M. Synthesis, pharmacological activity and hydrolytic behavior of glyceride prodrugs of ibuprofen. Eur. J. Med. Chem., v.40, p.371-376, 2005.

KUO, C.F.; TSAO, N.; CHOU, H.H.; LIU, Y.L.; HSIEH, W.C. Release of FITC-BSA from poly(l-lactic acid) microspheres analysis using flow cytometry. Colloids Surf., B, v.89, p.271-276, 2012.

LEO, E.; FORNI, F.; BERNABEI, M.T. Surface drug removal from ibuprofen-loaded PLA microspheres. Int. J. Pharm., v.196, p.1-9, 2000.

LI, M.; ROUAUD, O.; PONCELET, D. Microencapsulation by solvent evaporation: State of the art for process engineering approaches. Int. J. Pharm., v.363, p.26-39, 2008.

POUTON, C.W.; AKHTAR, S. Biosynthetic polyhydroxyalkanoates and their potential in drug delivery. Adv. Drug Deliv. Rev., v.18, p.133-162, 1996.

SASTRE, R.L.; OLMO, R.; TEIJÓN, C.; MUNÍZ, E.; TEIJÓN, J.M.; BLANCO, M.D. 5-Fluorouracil plasma levels and biodegradation of subcutaneously injected drug-loaded microspheres prepared by spray-drying poly(d,l-lactide) and poly(d,l-lactide-co-glycolide) polymers. Int. J. Pharm., v.338, p.180-190, 2007.

SILVA, A.H.; PRADO NETO, A.X.; GUIMARÃES, S.B. Electro-acupuncture reduces the need for additional anesthetics in experimental studies. Acta Cir. Bras., v.25, p.381-384, 2010.

THOMPSON, C.J.; HANSFORD, D.; HIGGINS, S.; ROSTRON, C.; HUTCHEON, G.A.; MUNDAY, D.L. Evaluation of ibuprofen-loaded microspheres prepared from novel copolyesters. Int. J. Pharm., v.329, p.53-61, 2007. 
UMEKI, N.; SATO, T.; HARADA, M.; TAKEDA, J.; IWAO, Y.; ITAI, S. Preparation and evaluation of biodegradable microspheres containing a new potent osteogenic compound and new synthetic polymers for sustained release. Int. $J$. Pharm., v.392, p.42-50, 2010.
WANG, C.; YE, W.; ZHENG, Y.; LIU, X.; TONG, Z. Fabrication of drug-loaded biodegradable microcapsules for controlled release by combination of solvent evaporation and layer-bylayer self-assembly. Int. J. Pharm., v.338, p.165-173, 2007.

Received for publication on $09^{\text {th }}$ February 2012 Accepted for publication on $25^{\text {th }}$ October 2012 